\title{
Chinese Historical Institutions and their Contribution for Global Governance
}

\author{
CAmilo Defelipe Villa*
}

Article Received: February 14, 2019
Article Accepted: May 5, 2019

Doi: https://doi.org/10.12804/revistas.urosario.edu.co/desafios/a.7677

To quate this article: Defelipe Villa, C. (2020). Chinese historical institutions and their contribution for global governance. Desafios, 32(1), 1-33. https://doi.org/10.12804/revistas. urosario.edu.co/desafios/a.7677

\begin{abstract}
This article makes an interpretation, from a historical institutional perspective, of the idea of Chinese wisdom and solutions for global governance introduced in the recent Chinese official discourse. Its main objective is to shed some light on the strength of the cultural values of China's historical institutions to negotiate the universalization of neoliberal values and normative standards. The article organization is as follows. First, it places the Chinese economic model within the concept of Sinicization. Second, it characterizes the continuity of the indigenous elements of that model, emphasizing the informal relational patterns of Chinese culture. Third, it questions the resilience of such values against the predatory effects of neoliberal style modernization and the government's reintroduction of traditional culture narratives. Fourth, it looks at some cases of collaborative local governance; finally, it provides some concluding remarks on the demonstrative role of Chinese historical institutions vis-à-vis the normative meaning of Chinese cultural wisdom and solutions for world governance. Keywords: Chinese wisdom and solutions, sinicization, institutions, informality, collaborative governance.
\end{abstract}

* Pontificia Universidad Javeriana (Bogotá, Colombia). East China Normal University. E-mail: camilo.defelipevilla@gmail.com. orcid: https://orcid.org/0000-0002-8022-9803 


\title{
Instituciones históricas chinas y su contribución para la gobernanza global
}

\begin{abstract}
Resumen
Este articulo bace una interpretación desde el institucionalismo bistórico de la idea de sabiduria y soluciones chinas para la gobernanza global introducida recientemente en el discurso oficial chino. Su objetivo principal es arrojar algunas luces sobre la fortaleza de los valores culturales de las instituciones históricas chinas para llegar a negociar la universalización de los valores y estándares normativos neoliberales. El articulo está organizado de la siguiente forma: primero, ubica el modelo de desarrollo chino dentro del concepto de sinización. Segundo, caracteriza la continuidad de los elementos autóctonos del modelo y enfatiza los patrones relacionales informales de la cultura china. Tercero, pone en duda la resiliencia de dichos patrones frente a los efectos predatorios de la modernización de tipo neoliberal y la reintroducción de narrativas de cultura tradicional porparte del gobierno. Cuarto, presenta algunos casos exitosos de gobernanza colaborativa basados en prácticas culturales; $y$, finalmente, sobre la base de todo lo anterior, a modo de conclusión provee comentarios sobre el rol ejemplificador de las instituciones históricas chinas frente al significado normativo de sabiduria y soluciones chinas para la gobernanza global.
\end{abstract}

Palabras clave: sabiduria y soluciones chinas, sinización, instituciones, informalidad, gobernanza colaborativa.

\section{Instituições históricas chinesas e sua contribuição para a governança global}

\begin{abstract}
Resumo
Este artigo faz uma interpretação desde o institucionalismo bistórico da ideia de 'sabedoria e soluções chinesas' para a governança global introduzida recentemente no discurso oficial chinês. Seu objetivo principal é lançar luzes sobre a fortaleza dos valores culturais das instituições históricas chinesas para chegar a negociar a universalização dos valores e standards normativos neoliberais. O artigo está organizado da seguinte forma: primeiro, localiza o modelo de desenvolvimento chinês dentro do conceito de sinização. Segundo, caracteriza a continuidade dos elementos autóctones do modelo
\end{abstract}


e enfatizando os padrões relacionais informais da cultura chinesa. Terceiro, põe em dívida a resiliencia de ditos padrões frente aos efeitos predatórios da modernização de tipo neoliberal e a reintrodução de narrativas de cultura tradicional por parte do governo. Quarto, apresenta alguns casos de sucesso de governança colaborativa baseada em práticas culturais e finalmente, sobre a base de todo o anterior, a modo de conclusão provê comentários sobre o papel exemplificador das instituições histórica chinesas frente ao significado normativo de 'sabedoria e soluçōes chinesas' para a governança global. Palavras-chave: sabedoria e soluções chinesas, sinização, instituições, informalidade, governança colaborativa.

\section{Introduction}

During the XIX Congress of the Chinese Communist Party in 2017, $\mathrm{Xi}$ Jinping laid out his vision for the world: "The Chinese people have always paid close attention and provided unselfish assistance to people who still live in war, turmoil, hunger, and poverty... China advocates that all issues in the world should be settled through consultation. In order to facilitate these efforts, [...] China will contribute more Chinese wisdom, Chinese solutions, and Chinese strength to the world" (Kewalramani, 2018).

These statements echo the World Economic Forum's concerns on how the problem of receding international multilateralism can increase the risks of domestic and global poverty and polarization. The Forum recommends that for addressing these issues, global leaders need to be able to manage technological change, strengthen the global cooperation system, bring around economic growth, reform market capitalism, and contribute towards the development of a green economy (World Economic Forum, 2017).

The World Economic Forum, however, is regarded as a platform for global neoliberal governance that naturalizes the Eurocentric and transatlantic liberal ontologies of what Pigman (2007) calls the "Standard of Market Civilization” (pp. 123-124). Despite being widespread, neoliberal governance has been challenged because the failure of its universalist policies and methodologies to correct the inequalities in different parts of the developing world. Also, in the post-Cold War 
order, many of the ontological and normative assumptions of the Market Civilization have been debated, negotiated, or contested by emerging states like China (Dian \& Menegazzi, 2018).

This contestation to neoliberalism suggests that China's non-western socio-historical legacies have not only responded to the standards of Market Civilization since the Reform and Opening-up of 1978, they will also play a key role as China reaches the status of global normative actor. China's independent foreign policy, its selective approach to multilateralism, and its historical and cultural self-representation imply that the country's offered solutions to pressing global issues, such as the ones defined by the World Economic Forum, will stem from both its command of norms and practices of international economic regimes and its indigenous institutional experiences. In this regard, either introducing new norms of development or reconfiguring the existing ones, will depend on how China tests its cultural institutions against the influence of standard global neoliberal values, standards, and practices.

With the formulation of the Belt and Road Initiative in 2013, Xi Jinping has turned to traditional Chinese cultural language and characteristics to give shape to ideal images of the world, integrating them with the spirit of Socialism. This vision has also been adopted as a starting point by different Chinese government officials and scholars in order to find alternatives to promote "exchanges and mutual learning between the Chinese and other civilizations". ${ }^{1}$

In this regard, Xi Jinping's Chinese or China's Dream puts together traditional Chinese philosophy, the idea of China's singularity, and the country's contribution to global governance. From a discursive perspective, a textbook interpretation of the expression of Chinese

\footnotetext{
1 As discussed by the author in a roundtable of the same topic at the in the Eighth World Forum on China Studies: China and the World: Progressing Together over 70 Years held in Shanghai on September 11th, 2019, organized by the State Council Information Office of the People's Republic of China, the Shanghai Municipal Government and the Shanghai Academy of Social Sciences.
} 
wisdom and Chinese solutions implies that culture shapes values, norms, practices, and soft norms for global governance.

\section{Objectives and Outline}

Drawing from the logic of the two-way socialization process (Pu, 2012) and Blaney and Tickner's (2017) Wordling, this article takes a look at the case of how emerging non-western powers, which were not first movers in the development of global regimes, could now redefine global governance in accordance to their indigenous cultural dynamics. Thus, this article explores the possibilities for the redefinition of Market Civilization standards and draws on general but recurrent patterns of Chinese cultural institutions to form a judgment about China's future role as a norm setter in a global governance context. Therefore, its central goal is to provide some insights about the relevance of Chinese cultural institutions' resilience and bargaining potential around current internationally accepted standards of development. In order to do that, the document will examine the meaning and normative potential of the notion of Chinese wisdom and solutions, based on the essential premises of the New Institutionalist approach. The author's principal claim is that informal institutions are at the core of such a notion. For instance, the article argues that the idea of cultural institutions — which includes philosophy and political discourse - is a mutually reinforcing process dating back to the origins of Chinese civilization and that its continuity could lend credibility to the discursive power of the Chinese wisdom and solutions idea.

In line with the work of Mahoney (2014), the notion of Chinese Wisdom and Chinese solutions is situates within a historical context in which the narrative of a "Chinese Dream" takes place. The "Chinese Dream" is a framing discourse that keeps a consistent historical narrative while addressing the difficult challenges that arise from development, party unity, and discipline (Mahoney, 2014). Methodologically, rather than following a philosophical or analytical discourse stance, this article borrows from Mahoney's assumptions and suggests a complementary institutionalist approach that considers the endurance of socio-cultural 


\section{6 / Camilo Defelipe Villa}

institutions as sources of the idea of Chinese Wisdom and Solutions. In order to do that, this manuscript will introduce and analyze concepts gathered from a literature review on New Institutionalism and Chinese practices.

This article is divided into four parts and a conclusion. The first section will describe China's discrepant relationship with neoliberalism and introduce Peter Katzenstein's concept of Sinicization in order to place China's cultural institutions within its unique civilizational dynamic. The second section traces the origins of China's relational institutions and provides an institutionalist framework to illustrate the historical continuity. The third section considers the conflict between these institutions and the effects of the market reforms in China. The fourth section explores some local cases of successful collaborative governance based on cultural practices; the final section concludes with a reflection of the demonstrative role of Chinese historical institutions.

\section{Framing the Chinese Historical Institutional Model}

China's modern institutional blueprint has followed a consistent historical pattern. Kirby (1994) and Fukuyama (2011) argue that centralism and authoritarianism have been at the core of China's political institutions in a roughly consistent way from pre-modern up to present times. The continuity of China's cultural and political traditions is what Katzenstein (2012) labels as a process of Sinicization.

Radical variants of Sinicization, holding beliefs about the supremacy of an authoritarian model of governance over a liberal one, emerged among intellectual and policy circles in China after 2008. Some of these authors sustain that Confucianism and Chinese socialism contradicted Fukuyama's idea of the End of History and reclaim cultural superiority over the "the Enlightenment features of European modernity such as political rights and free speech" (Mayer, 2018, p. 1227). Martin Jacques' (2012) controversial work suggests that a new version of a Sinocentric 
system will return in the twenty-first century on a global scale, making straightforward predictions on how China will replace the West.

The "Chinese development model" is probably the most widely discussed process of Sinicization. China's economic development is, to no small extent, the result of its integration with global markets and its commitment to the multilateral institutions that regulate them. However, the country's allegiance to developmental goals, economic liberalization, and globalization policies does not necessarily mean that China is fully committed to intrinsic neoliberal values and norms. The idea of a "Beijing Consensus", a term coined in 2004 in the mainstream media and think tank circles in the United States, has been used to pinpoint the Chinese development experience "miracle" within a neo-mercantilist system whose fiercest opponent is the neoliberal "Washington Consensus" model itself. However, a "Beijing Consensus" model has not been able to convey the actual existence of an economic system with Chinese characteristics (Hongyi, 2016, p. 25; Breslin, 2011, p. 1329).

Among the misconceptions about the Chinese development model, are the presence of Neoliberal traits. According to Nonini (2008), conceptually speaking, it is challenging to classify China within an all-encompassing definition of what makes a country Neoliberal. These misconceptions stem from the belief that the term "neoliberalism" is not monolithic and that there are instead different varieties of neoliberalism that are interpreted and put into practices relative to specific political goals. China's increasing economic reforms are deemed to be following a logic of neoliberal governance rather than the neoliberalism one. As an ideology and a process, Neoliberalism does not apply to Chinese policies because of the dominant role it places on rational, self-interested, entrepreneurial individuals. Instead, the Chinese model represents the kind of mixed economic system that is criticized by neoliberal thought, in which the distributive role of markets does not take place without state intervention.

Since the institutions prevailing at the center of the global system spread to other parts of it, as it is put forward by the Institutional 


\section{8 / Camilo Defelipe Villa}

Isomorphism approach (Di Maggio \& Powell, 1983), the actual operations of these institutions differ from country to country, often involving severe "decoupling" between form and substance. For instance, although China's "going out strategy" facilitated the formal adoption of internationally accepted standards of corporate social responsibility, the country's current practices significantly differ from the norm (Xue \& Hongying, 2017, p. 832). In other words, Neoliberalism did not find in China the same socio-historic processes that facilitated its emergence in the West.

The absence in China of a social base for a Neoliberal model meant that some of its elements had to be implemented gradually from the top. The result is a pragmatic logic of governance that is capable of allocating market-reform programs that contain elements of the IMF/ World Bank Model according to local circumstances in specific issues in different moments (Nonini, 2008, pp. 149-157; Hongyi, 2016; Breslin, 2011, p. 1337).

However, most of these views reduce China's multiple cultural identities and historical experiences to a monolithic idea of China (Kim, 2018) in an evident clash with the liberal western civilization. The views described above also correspond to what Kangasa and Salmenniemi (2016) affirm: an attempt to make the China-history fit into familiar patterns that represent the continuation of the three-worlds imagery, where the grasping of post-socialist transitions is made in terms of what they lack or where they have failed, concerning western-ideal types. Instead, as Tianbiao (2012) argues, one should think of China as "an aggregate of many traditions and know-how" acquired through time, that are not fixed but often interact with other types of values and traditions across time and space and therefore evolve constantly (Tianbiao, 2012, p. 100). China's rise is neither a rupture nor a return to history; instead, it is "the recombination of old and new patterns and components" (Katzenstein, 2012, p. 7). This "Vertical Sinicization" (Tianbiao, 2012) has been a constant in all of China's modernization processes up to current times and consequently, as the country acquires more responsibilities within international governance regimes, "a variety of economic processes of Sinicization 
can inflect globalization in the same way that Americanization and other civilizational processes have done" (p. 99).

China's emergence, therefore, translates into negotiations and exchanges with the global liberal order rather than remaking its foundational values and standards, as more radical versions of Sinicization and the Yellow threat theory otherwise suggest. The idea of a Chinese model under this perspective is more about the ability to reconcile conflicting economic systems than the adoption of a single system. China's development model consisted of stages and sequences of development that had to happen simultaneously rather than linearly. This idea of compressed development means that "different stages and sequences of development are collapsed into one single point in time" (Tianbiao, 2012, p. 118). Compressed development also meant catching-up with the standards of the world economy by reconciling neoliberal principles of economic efficiency and growth, with practices like informality, weak institutionalization, underdeveloped markets, state intervention, and lower standards.

Sinicization, as a process of civilization, thus occurs inside blurred boundaries, a grey convergence area, which includes institutional models and practices. This logic of reconciliation of contradictions implies an understanding of the political maneuvering capacity of the Chinese state to build, (re)adapt, combine, or contest governance regimes across time. This capacity to deal with compressed development, according to Hongyi (2016), is the result of pragmatic authoritarianism, which consists of a mix of elements of pre-socialist, socialist, and liberal practices within the political boundaries of order and development. Pragmatic authoritarianism is also flexible, gradual, adaptable, semi-formal, bureaucratic, meritocratic and experimental, and politically calculative (Hongyi, 2016, p. 57).

Additionally, pragmatic authoritarianism, like any other system of governance, occurs under an institutional structure that, as it will be described later, can be formal, informal, or both. In turn, Historical Institutionalism can help understand how the civilizational components of Sinicization are passed down through social and political 
institutions. Historical institutionalism is a reaction against the universalistic nature of its rational choice and places its attention on the long-term viability of institutions. Its essential claim is that institutions contain values and norms that persist in a roughly consistent pattern over time from the moment of their foundation (Peters, 1999, p. 56). In this regard, institutions are the backbone of Sinicization, and thus their historical continuity will also provide the unique patterns behind "Chinese solutions".

In this sense, there is hardly a Chinese economic model that China could transfer and promote beyond its borders. The country has not followed any development blueprint and has chosen instead to do what is best for itself based on its own strengths and constraints. China's experience can be regarded as an example of what is achievable if a State chooses its path rather than a pre-established model (Breslin, 2011, 1338). An analytical alternative is to look at the Chinese historical and socio-cultural contexts underpinning China's status as a global economic power. In order to do so, one may take a look at how the unfolding of China's history conformed to cultural norms and expectations. With the concept of Sinicization in mind, the next section will describe the Chinese historical institutional context.

\section{Institutional Continuity}

Institutions are the primary components of any civilizational prototype. For Davutoğlu (2014), a civilization prototype arises less for the institutional and formal reasons and more for the worldview that provides an individual with a meaningful basis of existence (p. 76). Such existence is based first on an ontological understanding of the self, second on the epistemological or how knowledge gives different answers to different questions, and third, on the value systems that define the interaction between ethics and law and the norms that standardize behavior in daily life (p. 79). Put together, ontology, epistemology, and axiology are elements implied in the classical definition of institution. An institution is a "relatively enduring collection of rules and organized practices, embedded in structures of meaning and resources that are relatively 
invariant in the face of turnover of individuals and relatively resilient to the idiosyncratic preferences and expectations of individuals and changing external circumstances" (March \& Olsen, 1989, 1995, as cited in March \& Olsen, 2006, p. 3).

Some core assumptions from the New Institutionalist approach in particular, such as history (Peters, 1999), culture (Finnemore, 1996), and cognitive structures (Palthe, 2014), embody the ontological, epistemological, and axiological processes of civilization described above. By extension, it is presumable that political discourses insert in that broader institutional context that echoes specific cultural and historical experiences. Institutions, therefore, bridge the ontological definition of individuals with their political life. For the case discussed here, it follows that institutions determine the Chinese civilizational dimension of Chinese Wisdom and Solutions.

Chinese civilization can be defined as the history of a network of social, cultural, and political institutions, shaped by patterns of hierarchy, order, and group or relational mentality, and legitimized and standardized by the metaphysical and philosophical discussions of Confucianism, Taoism, and later Buddhism. The pre-modern historical background of those patterns has had an effect on the developmental process of the People's Republic of China. Borrowing from the historical institutionalist approach, this past influence is explainable by the fact that institutions maintain their fundamental characteristics even though some of their constitutive elements change over time (Peters, 1999). From a reductionist perspective of historical institutional patterns, this means that institutions can learn and adapt to external influences, as Sinicization asserts.

For instance, keeping in mind a few New Institutionalism concepts, it is possible to trace back the origins of the patterns mentioned above. Just as the "the West" can find its roots in the ecological conditions of Europe and ancient Greek and Renaissance intellectual cultures, China is a product of a unique historical process of adaptation to geographic conditions that shaped its cognitive structures and later its cultural and developmental institutions. Earlier settlers thrived 
amid difficulties around the Yellow and Yangtze river basins (Dodgen, 2001; Fukuyama, 2011, pp. 124-126). Although these water sources provided stable food supply, frequent and irregular overflowing patterns caused people to regard themselves as simple objects of nature.

This organic relationship with nature helped mold a kind of cosmovision in which reality is understood as a cycle of occurrences. Such cosmovision first took an institutional form during the Xia (2070-1600 BCE), Shang (1600-1046 BCE), and Zhou (1046-256 BCE) dynasties, first with the rites of Shangdi (roughly translated as "the supreme deity") and later with the more elaborate "Mandate of Heaven" principle which put the Emperor, or the Son of Heaven, in charge of the "synchronization" between society and nature. The early Confucianism of the fifth century BC elaborated its own principles in accordance with the social order and metaphysical thought developed during the Zhou period. After a brief hiatus during the Qin dynasty (221-207 BCE), which introduced authoritarian centralization and standardization, the Han dynasty (206 BCE-220 CE) revived and institutionalized Confucianism for several centuries up until the beginning of the Tang (618-907 CE) dynasty, when Buddhism and Taoism drew most academic influence and popular support, in detriment of Confucianism. As a response, Neo-Confucian scholars from the end of the Song Dynasty (960-1279 CE) built on the early metaphysics and cosmological interpretations of humanity and integrated them into the Confucian sociopolitical order. The subsequent dynasties followed this pattern of authority, hierarchy, centralization, and mobilization for several centuries, ${ }^{2}$ even though the collapse of the imperial system in the nineteenth century, and until the present in a roughly consistent manner, as argued by Kirby (1994) and Ng-Quinn (2006).

\footnotetext{
2 A system of mutual supervision among people operated in imperial China to ensure collective compliance with the authority. This system of social control implemented from the top was later readapted by the Chinese Communist Party to imprint norms and values in favor of the country and to help maintain the stability and security of the political system (Toby, 2001).
} 
Additionally, geographic and ecologic conditions played a central role in shaping the Chinese historical institutions of hierarchy, collectivism, and authority. Confucianism, Taoism, and Legalism became philosophies and systems of rituals and symbols of such institutions. Confucianism, in particular, is at the core of China's institutional design. According to Wei-Bin Zhang (2000), Confucianism may be understood from two different angles. The first is

its basic vision, its basic principles, its philosophical structures, and its internal development [, while the second refers to] the manifestation of its principles [such as] the institutional structures, choice of officials through an examination system, the concept of Filial Piety, customs and ceremonies, the patterns and concepts of conscience of the population and actual forms and patterns of human interaction in traditional China which were influenced by or designed under the direction of Confucian principles (Wei-Bin, 2000, p. 2).

Confucianism has historically aimed at limiting the process of sociopolitical disintegration and restoring social stability by reworking inherited intellectual resources that later, as part of a mundane rather than a spiritual practice, will contribute to reaffirm and legitimize political power (Kim, 2018, pp. 24-27).

Confucianism was not the only intellectual development that had a dialectical relationship with history. The Qin Dynasty's (221-207 BCE) Legalist school, with its authoritarian statecraft, endured even after the establishment of the People's Republic of China in 1949. Moreover, Buddhism entered China and perdured, among other reasons, because it adapted to Chinese social characteristics (Xing, 2013). Confucianism and Taoism, however, are the basis of China's informal collectivist and relational institutions (Dittmer, Haruhiro \& Lee, 2000; Tsai, 2015). While the account above covered almost two millennia of civilizational consistency, this article is concerned with the inherited collective or relational mentality in the economic reforms of the People's Republic of China. The concept of slow-change institutions can explain the persistence of relationality in this period. 
Slow-change institutions, according to Gerard (2008), are values, beliefs, and social norms that change slowly over time. "Compared to social norms, political institutions may change more discontinuously; they may change little for prolonged periods, then change very abruptly. Social norms, on the other hand, tend to change continuously, albeit slowly [Slow-moving institutions are] by definition good candidates to influence fast-moving institutions since the former may change little at a time when the latter is changing dramatically" (Gerard, 2008, p. 13).

The same author argues that the interaction of slow- and fast-moving institutions — as it will be illustrated later- creates pressure for an institutional configuration that may be growth-enhancing or growth-inhibiting. This interaction is not one-sided: slow-moving institutions exercise causal pressures on fast-moving institutions, while the latter have a life of their own and can influence the path of slow-moving institutions (Gerard, 2008, p. 16).

Slow-change institutions can be considered a synonym of informal institutions, which have had a positive developmental effect in reformist China. In the same way, informality can be understood as a set of unwritten rules and hidden practices, sometimes detached from official discourse, used as a way to get things done, forgoing formal procedures, methods, and protocols. Informality often centers on "relationships that are not formalized or that take place outside formal contexts, precede formalization, resist articulation in dominant discourse and often emerge in covert or underground economies" (Ledeneva, 2018, p. 1), and occurs in instances of limited statehood (Risse, 2011). Likewise, informal governance is the application of informal rules; more precisely, it is made up of informal institutions of socially shared rules, usually unwritten, that are created, communicated and enforced outside official sanctioned channels (Gretchen \& Levitsky, 2004, p. 727, as cited in Ledeneva, 2018, p. 3). Informality at the political level is highly pragmatic; it involves doing what can be done through an expanded repertoire of tactics (Dittmer, et al., 2000, p. 302). Governance, therefore, may occur at the diffuse limit between formal and informal practices. 
Informality generally contradicts the notion of what is modern but not necessarily suitable for socioeconomic development. Informal institutions have existed in China throughout the country's history, including the pre-modern Confucian eras, the founding of the People's Republic and the Reform, and Opening-Up period. The Chinese economic system has generated enough dependence on these institutions to make their cost of replacing very expensive (Wilson, 2008). Despite the centralization and mass policy mobilization efforts after the establishment of the People's Republic of China in 1949, many economic activities remained outside of the central planning system. In vast rural areas, the grip of the state was relatively limited, which gave local cadres the freedom to act based on their needs and interests, implementing a culture of independent experimentation promoted by the central government (Heilmann, 2018, p. 51; Yuen Yuen, 2016, p. 42). As Yuen Yuen (2016) argues, China escaped the poverty trap by devising local solutions which included informal practices of capital accumulation from the bottom-up. Local officers' obligations were not limited to their officially assigned duties, but they were also expected to take on the task of securing investment by making extensive use of their personal connections. In other words, this method of investment promotion combined the private and public spheres, making it deliberately "not impersonal" (Yuen Yuen, 2016, p. 29).

It is possible arguing in this context that informal relationships managed to succeed because several market transaction elements - including money, debt, entrepreneurship, and property rights — embedded cultural values and symbolic representations. For instance, lending money to a close friend to start a business is as much a representation of the value of trust than it is a profit-motivated economic transaction. Thus, "a 'moral market' that is the relational logic formed by the coexistence of sociality, affect, and utility" (Mayfair, 2018) (re) appears and intertwines with markets of good and services to reduce transaction costs, while at the same time might bring about some corrupt practices (Schramm \& Taube, 2003, p. 279).

Slow-change institutions perdured even when the spiritual crisis of the May 4th Movement of 1919 and the Cultural Revolution (1967- 
1976) formally suppressed the Confucian imperial ideology, philosophy, and role for conduct. During these periods, some institutional cognitive elements of Confucianism endured under the Maoist political culture (Zhang \& Schwartz, 1997; Link, 2013; Davutoğlu, 2014, p. 81). In this sense, Kallio (2011) illustrates the Confucian spirit under Mao's ideology "the predicament of the Confucians in the imperial era was related to the difficulty of transforming one's inner moral nature (becoming a 'sage') into external instrumentalities, but Marxism at least partially solved the problem, especially through [Mao's] equation of practical, selfless work devoted to 'the people' and the inner dignity of the individual" (p. 166).

Nowadays, despite the implementation of the rule of law and the attempts to professionalize the organizational culture, the logic of informal transactions persists at different levels of governance, which translates into to China's poor performance in modern "standards of governance" indicators (Bertelsmann, 2018). In a nutshell, while the twentieth century posed important challenges to Confucianism, informal practices associated with it continued to shape Chinese society and values.

The analysis above suggests that the institutional development of China is consistent with its informal slow-change institutions, as the relational culture has imprinted the entire institutional design. In this regard, "Chinese solutions" should adhere to the non-predatory elements of this cultural, historical, and cognitive institutional logic. However, while a culturally-based informality can coexist with formal liberal policies, the uncontrolled effects of the later might disrupt the positive distributive effects of the former. The validation of the indigenous solutions implied in Xi Jinping's Chinese Wisdom and Solutions will depend on how the Chinese state addresses this issue.

\section{Historical institutions at stake?}

As it was suggested before, slow-change or informal institutions may not co-evolve at the same speed as fast-change or formal institutions. 
Peters (1999) asserts that powerful external forces may also break the historical pattern of institutions (p. 70). The cultural standards of market civilization and the disruptive effects of neoliberal policies could possibly threaten the Confucian moral base of relational institutions of modern Chinese society.

Arguably, these fast-change institutions can affect the way ideas such as family (a core concept in Confucianism), can permeate the cultural design of Chinese institutions. According to Quah (2008), when an individual faces stress - that is, the consequence of a change in the individual's life- it is his family who serves as the primary support system. However, in situations when stress overpasses the family's natural mechanism of relieve, the state must intervene in order to restore the order (pp. 161-163). In China, the concept of family has gradually evolved since dynastic and Maoist times, from being a morally-bound collective unit for conflict resolution, to a post-reform, two-party legally-bound contract and secular unit for private wealth accumulation (Ding \& Zhong, 2014, p. 441; Zurndorfer, 2004, pp. 14-16; King Whyte, 2005).

The liberal reforms of the seventies broke the "iron rice bowl", putting the replication of the Confucian informal culture and the traditional extended family and relation with authority mechanisms to a test. Some consequences of the introduction of market economy policies — namely urbanization, internal migrations, and the One-Child Policy — have created a generational problem. Migration to the cities has forced families to split up, leaving family members - especially stranded children — in situations of vulnerability (violence, substance abuse, and abandon, among others). At the same time, rising costs of living keep preventing young adults from starting a family, while those who are able to do so face a higher probability of divorce and often tend to rely financially on their parents (Mahoney, 2019). Additionally, consumerism and materialism compete with the dissemination of moral duties which, following the analysis of Lynch and Steele (2013), is a consequence of how the individualistic moral code originated in a context of marketization trumps the collectivist one in terms of what is essential for individuals and their subjective well-being. Evidence shows that increases in household consumption 
do not necessarily lead to a fulfilling life (Easterlin, Wang \& Wang, 2017), and that increasing job dissatisfaction and high labor turnovers are a symptom that traditional Chinese work values such as endurance, loyalty inside the organization, and guanxi are becoming irrelevant among Chinese workers (Wong, et al., 2001; Lu, et al., 2011, cited by Sousa-Poza \& Peng, 2017).

As the predominant relational institution (the family) risks erosion, both society and the Communist party have tried to reintroduce Confucian symbols and belief systems. According to Qin Pang (2019), while the destruction of a social order amid rapid social transformations encouraged Chinese societies to embrace Confucianism again, the Party has used this philosophy as an instrument to promote developmental and discursive goals and manage state-society relations.

In the early 1990s, certain groups of people, mainly businesspeople, entrepreneurs, and senior executives, began to show great enthusiasm about the traditional notion of the Confucian entrepreneur. They developed a keen interest in ancient Chinese philosophies such as Taoism, Chan - a Chinese version of Buddhism—, and especially Confucianism (Qin, 2019, p. 169) since it allowed them to obtain the social status and reputation that had been denied in the past by the Theory of the Three Representatives (Qin, 2019, pp. 174-175). Since entrepreneurs became a crucial element for the government's developmental goals, the Party had no choice but to give them the status they asked for in order to guarantee their support and to prevent them from threatening the party's ideological power. To prevent this threat from materializing, since the early 2000s, the Party has responded with a strategy that consists of matching the interests of entrepreneurs with a controlled diffusion of Confucian thought. The Central government allowed the establishment of different Confucian entrepreneurial and study associations and the creation of various activities sponsored by local governments in which senior officials from State-Owned Enterprises took part. In parallel, the development of a cultural entertainment market brought about lucrative business opportunities for cultural agencies and companies, which started providing substantial amounts of books, courses, ceremonial costumes, and other Confucian cultural products (Qin, 2019, 
p. 104). The objective of these activities was to co-opt entrepreneurs into a controlled Confucian narrative of corporate ethics and to have them invest in their own jurisdictions, town, province, etc.

Confucianism has also been restructured and compressed into a single narrative appropriated by the Communist Party. The use of symbols of traditional culture at the Beijing 2008 Summer Olympic ceremonies, the promotion of Confucius Institutes, and different exchange programs, among others, have brought traditional culture to a greater international audience. Similarly, the cultural rhetoric behind China's socialist modernization reform, known as the China Dream, has borrowed elements from the work of Chinese scholars interested in looking at the world through Chinese philosophical lenses. For instance, Xi Jinping's "China Dream" has been championed by Qiang Shigong, a conservative legal scholar from Peking University's Law School and public intellectual, who interprets Xi Jinping thought as an amalgamation of traditional Chinese thought and Marxism Kallio (2018). In Qiang's analysis, Xi's communism is "a kind of ideal faith or a spiritual belief." Its goal in some distant future is not the realization of the Marxist utopia, but an era of "great communality under Heaven” (Tianxia Datong) to prevails (Kallio, 2018, p. 4).

However as Dotson (2011), Kallio (2011), Zurndorfer (2004), Mayer (2018), and Kim (2018) point out, what is found at the bottom of this restoration is an anachronic narrative reintroducing both Confucianism and traditional thought in the political discourse and capacity of the Party to dominate and Confucianism rather than the other way around. The Party has purposefully clouded the differences between Asian values, traditional studies, Confucianism, and socialist harmony because "it does not want to see an overemphasis on Confucianism while it is also not of the interest of the people to differentiate between Confucianism and other elements of Chinese culture" (Kallio, 2011, p. 148). Therefore, the use of traditional thought, as a mean to "fill the spiritual vacuum" or to "create a political religion" (Kallio, 2011, p. 73), is more oriented towards disciplining society around the political system, rather than addressing the erosion of the nation's deeper cultural institutional structure. 
Similarly, as Lin (2013) argues, the combination of wealth and social welfare distribution conflicts, if unaddressed, has the potential of negatively affect state-society relations as China advances towards further economic liberalization and integration in world markets. Moreover, Chinese society is especially susceptible to the negative economic and social transformations that come from modernization and globalization. Nevertheless, its real vulnerability will depend on the capacity of Beijing to respond to those changes in a way that is consistent with China's indigenous institutions and the promise of a modern country holding a leadership role in global integration and free trade systems. Additionally, as it is put forward by Gérard (2008), "countries with different cultural and historical paths must find within their existing slow-moving institutions the roots for changes in their fast-moving institution" (p. 18). Therefore, uncontrolled liberal reforms will not contribute to enhance China's capacity for socio-political self-organization or provide innovate wisdom and solutions from her civilizational repertoire.

To validate Chinese solutions, Chinese leadership must act in tandem with cultural institutions in order to deliver effective governance. Normative institutionalism asserts that individuals not only seek to maximize utility but also to replicate the values of the institutions they belong to (Peters, 1999, p. 26). Institutions, according to Palthe (2014), are made up of interactions between regulative, normative, and cognitive elements. The regulative dimension of institutions refers specifically to changes brought about by market forces and organizational policies - which are enforced through formal, coercive means-, while normative features touch on the role of social obligations and the informal structures of organizational culture (Palthe, 2014). Lastly, and especially relevant for the social issues addressed above, there is the cognitive dimension of organizations. Cognition refers to beliefs, mental models, and interpretations of shared meanings when organizations go through change; in other words, it is the psychological foundation of the acceptance of change: "From the cognitive perspective, for genuine organizational change to be produced and sustained, the premises of change would need to be internalized and valued by organizational members. Here, members 
choose to adopt and support a change because they believe in it and personally want to support it, even if it is not enforced through an organizational policy (regulative) or workplace norm (normative)" (Palthe, 2014, p. 61).

Cognition can be defined as what Herrmann-Pillath (2010) describes as cultural forms of emotionality, which enable the bonding necessary — at a social level — for the effective use of social capital (p. 23). Is precisely Confucianism what dictates these forms of emotionality in social bonds, which are being challenged by the consequences of modernization described before. Thus, when change is consistent with the receiver's conceptual beliefs, the necessary cognitive change is likely to be accepted. These three aspects of institutions are important because their interaction can make institutional change legitimate and organizational survival possible amidst change (Palthe, 2014, p. 63).

Arguably, and following Quah (2008), the way the normative and cognitive dimensions of Confucian institutions can survive in a context of liberal globalization starts with an intervention in the family unit, which means pushing for the enforcement of family protection laws enacted in the last three decades. The Party must also uphold its commitment to people and socialism embedded in indigenous traditions (Lin, 2013, p. 128). Just as strong, domestic, formal institutions allow a state to respond to or influence international regimes (Mattli \& Büthe, 2003), informal institutions must set a precedent on how to resist the predatory effects of neoliberal globalization and establish practices for alternative development. China's influence in the world over the next few decades will largely depend on what kind of leadership Beijing can provide (Xuetong, 2011, p. 259). Since the promotion of the government's Chinese Solutions and Wisdom is a process of Sinicization, preserving the positive attributes of its historical institutions could allow China to garner moral assets in order to become a leader in international norm-making.

One way to do this is to reclaim the values of the relational logic of China's organizational culture. As the discussion will follow below, this implies promoting the autonomy of civil society according to 
local, informal, cultural norms. The next section will take a look at some recent examples of successful informal governance.

\section{Learning from Grassroots}

The concept of informality contradicts the notion of what is considered to be modern and appropriate practice. For instance, trust in informal economic transactions illustrates this contradiction. For Shaomin Li \& Jun (2010), "most conceptualizations of trust by economic and business scholars can be summarized in two views. One focuses on personal traits that characterize trust, such as consistent, responsible, and fair (e.g., Dwyer \& LaGace, 1986), while the other view emphasizes the perceived outcomes of trust, such as the expectations that a trusted partner will deliver the promised results (e.g., Anderson \& Narus, 1990)" (Shaomin Li \& Jun, 2010, p. 135).

Trust for the authors cited above is a culture of commonly observed social norms and values that have taken shape throughout the long history of horizontal networks of association between people in social, economic, and political exchanges (Putnam, 1993, as cited by Shaomin Li \& Jun, 2010, pp. 136-137). They also argue that in a society with a high level of trust, corruption tends to be more efficiency-enhancing (that is less harmful to economic growth), whereas, in a society that lacks it, corruption tends to be more predatory (more harmful to economic growth).

While post-communist China evidences the efficiency effects of trust, post-communist Russia reveals its predatory effects. According to Hsu (2005), trust produces positive developmental results when it is generalized rather than particularized (Shaomin Li \& Jun, 2010). In the context of the transition of China and Russia towards a market economy, the private exchange of favors was common practice in both countries' informal culture. As these economies transited through the hindrances of incomplete legal reforms in the nineties, informal favor exchange balanced out for the lack of formal rules. In the case of China, trust-based Guanxi allowed business transactions to 
succeed and establish an enduring capitalist system without contracts. By contrast, in post-soviet Russia, similar practices, such as Blat, did not allow for trust to be built and instead gave way to corrupt and predatory behaviors.

Trust has played a crucial role in Chinese reforms, from the opening period up to the present. In the 2012 World Values Survey, $60 \%$ of surveyed Chinese citizens agreed with the statement that most people could be trusted, ranking second in the world —only behind the Netherlands - and higher than many traditional democracies such as the United States, Taiwan, Japan, and South Korea, where only around $30 \%$ of citizens declared to trust each other. The findings in this report seem to support the case for generalized trust in the context of both China and Russia, analyzed above; in the words of Tang (2018): "While family trust is very high in China, it is not the most important reason for the high level of general trust [...]. Instead, community-based trust turned out to be most closely related to general trust in China" (parr. 20).

The phenomenon of generalized trust in Chinese culture reconciles informal or slow-change institutions with formal or fast-change institutions. If development entails transforming a society's traditional relations, ways of thinking, policies, and means of productions into more "modern ways" (Bowden \& Seabroke, 2006, p. 211), then Chinese informal relational institutions like Guanxi should be substituted, possibly with the rule of law of neoliberal standards. However, the sudden imposition of such formal norms could fracture the cognitive dimension of institutions, which in turn may cause a rupture on the rest of the normative and regulative elements of neoliberal policies.

The absence of community-building values in trust networks is what separates informality as a positive mechanism of governance from corruption. A relational mindset can yield positive outcomes if it is grounded in positive shared values and ethical practices. Informal relationships in developing and transition economies can become positive attributes of "collaborative Governance" under conditions of limited statehood when collaborative networks serve the public 
interest (Long \& Jin, 2016, p. 13; Zhimin \& Yijia, 2015). China constitutes a case in which the government, social organizations, private firms, and individuals have engaged in collaborative governance.

A leading study on informal governance by Tsai (2007), examined how the question of shared values can help explain why different local governments with the same level of economic development or the same type of formal institutions can behave differently. Taking two village settlements as examples, the study found that when government officials are subject to informal, unwritten rules and norms that have not been approved by the state but instead instituted and enforced by particular communities, the officials still feel the obligation to provide basic public goods since they are aware that the group's informal norms and networks can be used as punishment if they fail to fulfill their duties. Moreover, community leaders are able to earn additional moral standing through public activities that allow them to demonstrate how their behavior adheres to, or even surpasses, accepted informal standards.

Similarly, analyzes by Long and Jin (2016) found that informal ties between private firms and local governments in China have an impact on the country's business dynamics. They review the altruistic motivation theory, which states that when "corporate philanthropy is motivated by managers' sense of social responsibility or altruism (Campbell, Gulas \& Gruca, 1999; Edmondson \& Carroll, 1999; Sánchez, 2000, as cited in Long \& Jin, 2016, p. 2), corporate managers would support charity even though these acts would have little or no effect on the firm profits (Frey \& Meier, 2004)" (Long \& Jin, 2016, p. 2), and propose a strategic motivation argument that in turn states that companies can secure access to official sources of financing if they, in return, make contributions to charity (Long \& Jin, 2016).

Governments also can trigger collaborative governance while sound political and economic institutions can positively reinforce trust within informal governance networks (La Porta, Lopez-de-Silanes, Shleifer \& Vishny, 2000). The rebirth of the idea of community (shequ) in the nineties responded to the need to assist the central governments 
with the social challenges brought about by economic reform. For this purpose, communities were established as the most basic unit for the urban, social, political, and administrative organization with the capacity to offer a variety of social services to people with different needs. Communities grew to become units of self-governance, meaning that the government eventually granted them autonomy to develop their own methods to build or restore the moral fabric of society. In this sense, communities represent a case of both formal and informal governance founded on shared moral values (Bray, 2006).

Leaders in any position of power can also cultivate moral qualities. Following Hackett \& Wang (2012), a leader's management capabilities (knowledge, skills, abilities, personality, and experience) have proven insufficient to limit corruption at the top. Leadership is also about the virtues and values that forge character, which involves less quantifiable dimensions of human behavior. Organizations are required then to measure and assess the moral virtues of leaders. According to Min, Xu \& Chan (2012), when firm supervisors show compassionate behaviors towards their subordinates - triggering social exchanges and inducing positive emotions - the latter will develop trust with their supervisors and feel the obligation to respond in turn with better work performance and by taking on additional tasks in order to support their supervisors and the organizations they represent. On the other hand, authoritarian leadership is likely to spur unfavorable social exchanges leading to a pattern of distrust between supervisors and subordinates, which can, in turn, reduce in-role and extra-role performance (p. 634). In a broader sense, Zhang, Jia, and Gu (2012) show that when political leaders need to control crises (e.g., natural disasters), value-congruence between leaders and subordinates is critical to encourage the latter to carry out commands more effectively and efficiently.

The examples described above show the importance of building more extensive networks of collaborative governance based on informal local rules. Moral relationships are the most critical element of informal governance and must be protected by any individual or organization holding a position of authority. For this reason, the pressure exerted by modernization, uncontrolled free markets, and 
consumerist culture should not be powerful enough to transform the moral values of relationships at any node of the social network.

\section{Conclusion: Chinese Wisdom and Solutions for Global Governance}

This article made the case for institutions as models for designing and promoting Chinese Wisdom and Solutions. It has been argued that its origins lay not only in Chinese philosophy and ideology but also in the strength of the relationality of Chinese indigenous institutions. It was also claimed that historical patterns of hierarchy, order, and group or relational mentality help define Chinese political and socio-cultural institutions and, therefore, have contributed to China's economic transformation. Rapid modernization, however, is posing a challenge to the Confucian cultural ideal represented by the institution of family. The document also referenced, based on Chinese experiences, how informal collaborative governance can materialize in any place in which the individuals holding positions of authority promote cultural values such as trust and self-reliance.

Given that the process of modernization will continue, a crucial condition for success will consist of finding the way to bring traditional local practices together with recent developments like the opening up of China's financial and goods and the services markets. In this sense, projects such as the Belt and Road Initiative do not attempt to alter the economic and political models of developing countries while at the same time seek to increase the representation of these countries in the international economic order (Dian \& Menegazzi, 2018). For instance, in order to become a genuine civilizational initiative, China's Wisdom and Solutions must promote collaborative governance based on local cultural institutions. Chinese Wisdom and Solutions should as well be consistent with the cultural institutions at home, so they can truly be "Chinese" in a cultural or civilizational sense. Moreover, China must as well settle the cultural contradictions brought about by an uncontrolled modernization and set the 
corresponding normative example for the rest of the world through the Belt and Road Initiative.

From this broad discussion, it is possible to conclude that the role of informal institutions for socio-economic development is one of China's most important contributions to global governance. "Wisdom" stands for cultural morals, while "Solutions" does the same for informal governance mechanisms. Although these cannot be adopted in a context different from the Chinese, each country must reclaim its cultural institutions and integrate them into its national development policies. In other words, Chinese Wisdom and Solutions indicates an exercise of local resistance.

Wisdom, in particular, is rooted in Confucianism: lead by virtuous example. In this sense, the state must provide the incentives necessary for individuals to internalize altruistic behaviors and, in the same way, strengthen a society based on trust. Leading by example can bear fruit if a state succeeds in controlling the predatory effects of the market economy. On a technical level, virtuosity can translate into the promotion and improved provision of global public goods that foster human empowerment, for value-based trust to be built. The effectiveness of such an approach can, in turn, lay the ground in order to become a norm entrepreneur in the global system.

It is worth to bear in mind that "western wisdom and solutions" are no stranger to collaborative governance and humane leadership. As Hackett and Wang (2012) assert, there are leadership virtuosity attributes that are common to the Confucian and Aristotelian traditions. Hence, it is possible to conclude that civilization and its institutions are not monothetic but fluid; ergo, bridges for mutual understanding will always exist.

Finally, for future research, it is important to look at whether China will promote a global network of alternative normative and productive standards. 


\section{References}

Bertelsmann, S. (2018). BTI country report-China. Retrieved from https:// www.bti-project.org/en/reports/country-reports/detail/itc/chn/

Blaney, D. \& Tickner, A. (2017). Worlding, ontological politics and the possibility of a decolonial IR. Millennium: Journal of International Studies, 45(3), 293-311.

Bowden, B. \& Seabroke, L. (2006). Civilizing markets through global standards. In B. Bowden \& L. Seabroke (Eds.), Global standards of market civilization (pp. 3-16). New York: Routledge.

Bray, D. (2006). Building 'community': new strategies of governance in urban China. Economy and Society, 35(40), 530-549.

Breslin, S. (2011). The 'China model' and the global crisis: from Friedrich List to a Chinese mode of governance? International Affairs, 87(6), 1323-1343. https://doi.org/10.1111/j.1468-2346.2011.01039.x

Davutoğlu, A. (2014). The formative parameters of civilizations. In F. Dallmayr, M. A. Kayapinar \& I. Yaylaci (Eds.), Civilizations and world order: geopolitics and cultural difference (pp. 73-97). Lanham: Lexington Books.

Di Maggio, P. \& Powell, W. (1983). The iron cage revisited: institutional isomorphism and collective rationality in organizational fields. American Sociological Review, 48(2), 147-160. https://doi.org/10.2307/2095101

Dian, M. \& Menegazzi, S. (2018). The origin of China's ideational narratives. In New regional initiatives in China's foreign policy (pp. 26-45). Springer International Publishing.

Ding, X. \& Zhong, Y. (2014). Towards a thick description of Chinese family and political culture: Confucianism, socialism and liberalism in China. Frontiers of Law in China, 9(3). https://doi.org/10.3868/ s050-003-014-0025-2

Dittmer, L., Haruhiro, F. \& Lee, P. N. S. (Eds.). (2000). Informal politics in East Asia. Cambridge University Press. https://doi.org/10.1017/ CBO9780511629495

Dodgen, R. A. (2001). Controlling the dragon Confucian engineers and the yellow river in late imperial China. Honolulu: University of Hawai'i Press.

Dotson, J. (2011). The Confucian revival in the propaganda narratives of the Chinese government. Retrieved from https://www.uscc.gov/sites/default/files/ Research/Confucian_Revival_Paper.pdf 
Easterlin, R. A., Wang, F. \& Wang, S. (2017). World happiness report. In Growth and happiness in China, 1990-2015. Retrieved from https:// s3.amazonaws.com/happiness-report/2017/HR17-Ch3.pdf

Finnemore, M. (1996). Norms, culture and world politics: insights from sociology's institutionalism. International Organization, 50(2), 325-347.

Fukuyama, F. (2011). The origins of political order. New York: Farrar, Straus and Giroux.

Gérard, R. (2008). Understanding institutional change: fast-moving and slow-moving institutions. In J. Kornai, L. Matyás \& G. Roland (Eds.), Institutional change and economic behaviour (pp. 134-159). London: Palgrave Macmillan.

Hackett, R. D. \& Wang, G. (2012). Virtues and leadership: an integrating conceptual framework founded in Aristotelian and Confucian perspectives on virtues. Management Decision, 50(5), 868-899.

Heilmann, S. (2018). Red swan: how unorthodox policy making facilitated China's rise. Hong Kong: The Chinese University Press.

Herrmann-Pillath, C. (2010). Social capital, Chinese style: individualism, relational collectivism and the cultural embeddedness of the institutions-performance link. China Economic Journal, 2(3), 325-350.

Hongyi, L. (2016). China's governance model: flexibility and durability of pragmatic authoritarianism. New York: Routledge.

Hsu, C. L. (2005). Capitalism without contracts versus capitalists without capitalism: comparing the influence of Chinese guanxi and Russian blat on marketization. Communist and Post-Communist Studies, 38(7), 309327. https://doi.org/10.1016/j.postcomstud.2005.06.003

Jacques, M. (2012). When China rules the world: the rise of the middle kingdom and the end of the Western world. New York: Penguin Books.

Kallio, J. (2011). Traditions in Chinese politics. FILA Report, (27). Retrieved from https://www.fiia.fi/en/publication/tradition-in-chinese-politics

Kallio, J. (2018). Xi Jinping thought and China's future foreign policy: multipolarity with Chinese characteristics. FILA Briefing Paper, (243). Retrieved from https://www.fiia.fi/en/publication/xi-jinping-thought-and-chinas-future-foreign-policy

Kangasa, A. \& Salmenniemi, S. (2016). Decolonizing knowledge: neoliberalism beyond the three worlds. Journal of Social Theory, 17(2), 210-227. https://doi.org/10.1080/1600910X.2016.1184174 
Katzenstein, P. (2012). China's rise: rupture, return, or recombination? In P. Katzenstein (Ed.), Civilizational processes beyond East and West (pp. 1-38). New York: Routledge.

Kewalramani, M. (2018). China's flawed model for peace. The Diplomat. Retrieved from https://thediplomat.com/2018/04/chinas-flawedmodel-for-peace/

Kim, Y. (2018). A bistory of Chinese political thought. Cambridge: Polity Press.

King Whyte, M. (2005). Continuity and change in Chinese urban family life. The China Journal, (53), 9-33. https:// doi.org/10.2307/20065990 Kirby, W. (1994). Traditions of centrality, authority and management in modern China's foreign relations. In T. Robinson \& D. Shambaugh (Eds.), Chinese foreign policy: theory and practice (pp. 13-29). Oxford University Press.

La Porta, R., Lopez-de-Silanes, F., Shleifer, A. \& Vishny, R. (2000). Investor protection and corporate governance. Journal of Financial Economics, 58(1-2), 3-27. https://doi.org/10.1016/S0304-405X(00)00065-9

Ledeneva, A. (2018). Introduction: the informal view of the world - key challenges and main findings of the Global Informality Project. In A. Ledeneva (Ed.), The global encyclopaedia of informality: understanding social and cultural complexity. Vol. 1 (pp. 1-27). London: UCL Press.

Lin, C. (2013). China y el capitalismo global: reflexiones sobre marxismo, historia y politica. Barcelona: El Viejo Topo.

Link, P. (2013). An anatomy of Chinese: rhythm, metaphor, politics. Harvard University Press.

Long, C. \& Jin, Y. (2016). What explains Chinese private entrepreneurs' charitable behaviors? A story of dynamic reciprocal relationship between firms and the government. China Economic Review, 40, 1-16. https://doi.org/10.1016/j.chieco.2016.05.001

Lynch, M. S. \& Steele, G. L. (2013). The pursuit of happiness in China: individualism, collectivism, and subjective well-being during China's economic and social transformation. Social Indicators Research, 114(2), 441-451. https://doi.org/10.1007/s11205-012-0154-1

Mahoney, J. G. (2014). Interpreting the Chinese dream: an excercise of political hermeneutics. Journal of Chinese Political Science, 19(1), 15-34. https://doi.org/10.1007/s11366-013-9273-z

Mahoney, J. G. (2019). A century on from the May Fourth protests, Chinese youths are in a state of crisis. South China Morning Post. Retrieved from 
https://www.scmp.com/comment/insight-opinion/article/3008625/ century-may-fourth-protests-chinese-youths-are-state-crisis

March, J. G. \& Olsen, J. P. (2006). Elaborating the "new institutionalism". En R. Rhodes, S. Binder \& B. A. Rockman (Eds.), The Oxford handbook of political institutions (pp. 3-20). Oxford: Oxford University Press.

Mattli, W. \& Büthe, T. (2003). Setting international standards: technological rationality or primacy of power? World Politics, 56(1), 1-42. https:// doi.org/10.1353/wp.2004.0006

Mayer, M. (2018). China's historical statecraft and the return of history. International Affairs, 94(6), 1217-1235. https://doi.org/10.1093/ia/iiy209

Mayfair, Y. (2018). Guanxi (China). In A. Ledeneva (Ed.), The global enciclopaedia of informality: understanding social and cultural complexity. Vol. 1 (pp. 75-79). London: UCL Press.

Min, W., Xu, H. \& Chan, S. (2012). The influencing mechanisms of paternalistic leadership in Mainland China. Asia Pacific Business Review, 18(4), 631-648. https://doi.org/10.1080/13602381.2012.690940

Ng-Quinn, M. (2006). The normative justification of traditional Chinese authoritarianism. Critical Review of International Social and Political Philosophy, 9(3), 379-397. https:/ / doi.org/10.1080/13698230600900925

Nonini, D. M. (2008). Is China becoming neoliberal? Critique of Anthropology, 82(2), 145-176. https://doi.org/10.1177/0308275X08091364

Palthe, J. (2014). Regulative, normative, and cognitive elements of organizations: implications for managing change. Management and Organizational Studies, 1(2), 59-66. https://doi.org/10.5430/mos.v1n2p59

Peters, G. G. (1999). The legacy of the past: historical institutionalism. In G. G. Peters (Ed.), Institutional theory in political science: the "new institutionalism” (pp. 97-111). New York: Pinter.

Pigman, G. A. (2007). Engaging the critics. In G. A. Pigman (Ed.), The World Economic Forum, a multi-stakeholder approach to global governance (pp. 123137). New York: Routledge.

$\mathrm{Pu}, \mathrm{X}$. (2012). Socialization as a two-way process: emerging powers and the diffusion of international norms. The Chinese Journal of International Politics, 5(4), 341-367. https://doi.org/10.1093/cjip/pos017

Qin, P. (2019). Confucianism with consent: the revival of "Confucian entrepreneur" and the Chinese state's responses. In P. Qin (Ed.), State-society relations and Confucian revivalism in contemporary China (pp. 161-195). 
Singapore: Palgrave Macmillan. https://doi.org/10.1007/978-98110-8312-9_5

Quah, S. (2008). Families in Asia: home and kind. London: Routledge.

Risse, T. (Ed.). (2011). Governance without a state? Policies and politics in areas of limited statehood. Columbia University Press.

Schramm, M. \& Taube, M. (2003). The institutional economics of legal institutions, guanxi, and corruption in the PR China. In Fighting corruption in Asia (pp. 271-296). World Scientific Publishing. https://doi. org/10.1142/9789812795397_0011

Shaomin Li, L. \& Jun, W. (2010). Why some countries thrive despite corruption: the role of trust in the corruption-efficiency relationship. Review of International Political Economy, 17(1), 129-154. https://doi. org/10.1080/09692290802577446

Sousa-Poza, A. \& Peng, N. (2017). What Chinese workers value: an analysis of job satisfaction, job expectations, and labor turnover in China. Retrieved from http://ftp.iza.org/dp10963.pdf

Tang, W. (2018). The "surprise" of authoritarian resilience in China. American Affairs, 2(1). Retrieved from https://americanaffairsjournal.org/2018/02/surprise-authoritarian-resilience-china/?fbclid= IwAR0FX3YVPB_8xdNIWRRtO3JmyLB86esZGXE77fYVy 5DI766CpvFkq0UOsA8\#notes

Tianbiao, Z. (2012). Compressed development, flexible practices and multiple traditions in China's rise. In P. Katzenstein (Ed.), Sinicization and the rise of China: civilizational processes beyond east and west (pp. 99-119). New York: Routledge.

Toby, H. (2001). A letter from China: social control in China. A formal or an informal mechanism? Crime Prevention and Community Safety, 3(1), 71-85. https://doi.org/10.1057/palgrave.cpcs.8140083

Tsai, K. (2015). China: economic liberalization adaptative informal institutions and party-state resilience. In S. Leibfried, E. Huber, M. Lange, J. D. Levy, F. Nullmeier \& J. D. Stephens (Eds.), The Oxford handbook of transformations of the state (pp. 654-670). Oxford University Press.

Tsai, L. (2007). Accountability without democracy: solidarity groups and public provision in rural China. Cambridge University Press.

Wei-Bin, Z. (2000). Introduction. In Z. Wei-Bin, Confucianism and modernization: industrialization and democratization of the Confucian regions (pp. 1-10). Palgrave Macmillan. 
Wilson, S. (2008). Law guanxi: MNCs, state actors, and legal reform in China. Journal of Contemporary China, 17(54), 25-51. https://doi. org/10.1080/10670560701693062

World Economic Forum. (2017). The global risks report 2017. Genova: World Economic Forum. Retrieved from http://www3.weforum.org/docs/ GRR17_Report_web.pdf

Xing, G. (2013). Buddhist impact on Chinese culture. Asian Philosophy, 23(4), 305-322.

Xue, Y. H. \& Hongying, W. (2017). China's "going-out" strategy and corporate social responsibility: preliminary evidence of a social responsibility: preliminary evidence of a "boomerang effect". Journal of Contemporary China, 26(108), 820-833. https://doi.org/ 10.1080/10670564.2017.1337301

Xuetong, Y. (2011). International leadership and norm evolution. The Chinese Journal of International Politics, 4(3), 233-264. https:/ / doi.org/10.1093/ cjip/por013

Yuen, A. (2016). How China escaped the poverty trap. Cornell University Press. Zhang, T. \& Schwartz, T. (1997). Confucius and the Cultural Revolution: a study in collective memory. International Journal of Politics, Culture and Society, 11(2), 1889-212.

Zhang, Z., Jia, M. \& Gu, L. (2012). Transformational leadership in crisis situations: evidence from the people's Republic of China. The International Journal of Human Resource Management, 23(19), 4085-4109. https:/ / doi.org/10.1080/09585192.2011.639027

Zhimin, C. \& Yijia, J. (Eds.). (2015). The road to collaborative governance in China. Singapore: Palgrave Macmillan.

Zurndorfer, H. T. (2004, June 4). Confusing Confucianism with capitalism: culture as impediment and/or stimulus to Chinese economic development. Paper presented at the Third Conference of the Global History Development Network, Konstanz, Germany. 